\title{
Predestinasi
}

Volume 13, No. 2, Desember 2020, Hal. 79-92

ISSN (Print): 1978-9351

\section{Kantian Ethics And The Hesc Research: A Philosophical Exploration}

\author{
Chris O. Abakare \\ Department of Philosophy, \\ Nnamdi Azikiwe University, Awka, Anambra State, Nigeria. \\ *e-mail: chrisabakare@gmail.com
}

\begin{abstract}
The scientific reports on the successful use of Human Embryonic Stem cells to cure many sicknesses as provoked a long-standing controversy about the ethics of research involving human embryos. This controversy arises from sharply differing moral views regarding the use of embryos for research purposes. Indeed, an earnest international scholarly debate continues till today over the ethical, legal, and medical issues that arise in this arena. Immanuel Kant (1724-1804) had given a moral guideline that ethical decisions should be made by considering the nature of the act itself, not its consequences. Furthermore, Kant has warned that persons (autonomous agents) have a special moral worth or dignity, which is the basis for the respect that is owed to them. Thus, respect for persons, means never using persons merely as means to our ends, but always treating them also as ends in themselves. Some philosophers like Richard Doerflinger, Michael Novak, Gilbert Meilaender, and Robert P. George have used the Kantian formula of humanity to criticize the argument that spare IVF embryos can be used for stem cell research given their inevitable death and thus lack of properties for future life. However, the purpose of this paper is to take a critical look at the Human Embryonic Stem cells subject matter to investigate the concept of "personhood', with the maxim of 'never treating a person as a means'. This paper argues that if we accepts the definition of a person to possess capacities such as 'rational' 'will' and 'selfdetermination', then IVF embryos is not a person and can therefore be researched upon, used to derive human embryonic stem cells. Hence, Human Embryonic Stem cells research can be carried out within the ambiance of Kant Categorical Imperative without moral conflict.
\end{abstract}

Keywords: Immanuel Kant; Categorical Imperative; Human Embryonic Stem Cell.

\section{INTRODUCTION}

Immanuel Kant devised the Categorical Imperative which was designed to form the basis of all moral obligations. A categorical imperative would be one that represented an action as objectively necessary in itself apart from its relation to a further end (Kitcher 2014). Kant's 'categorical imperative' is an example of the highest moral principle. The principle determines the requirements for maxims that are morally acceptable. Kant 'Categorical Imperative' simply states that humans should Act in such a way that we always treat humanity, whether in person or the person of any other, never simply as a means, but always at the same time as an end. With the 'end in itself' principle Kant offers basic content for these principles. Since it is the highest principle it is open to more specific applications, as he shows in the Metaphysics of Morals where he offers some specification of the principle in the legal sphere and in more private life. 


\author{
80 Predestinasi \\ Volume 13, No. 2, Desember 2020 Hal. 79-92
}

When a Kantian applies a categorical imperative to the issue of embryo research they would often use the phrase, 'always preserve human life'. This would make embryo research and research on the fetus wrong, without exception, on Kantian grounds. In general, research on embryos may violate Kant's categorical imperative, because firstly, in stem cell research the embryo is killed to extract the cells and secondly, to freeze embryos is simply to use them as a means to an end not an end in themselves. Some commentators apply Kant's Categorical Imperative to embryos to mean that we should never treat embryos as a means to an end (i.e. use them for what they can provide), rather we should treat them as means themselves (Myskja 2008). In this sense, we should treat embryos as though they are persons, had full moral status and take all possible steps to protect them and help them fulfill their potential to become full human beings. If this approach was enshrined in legislation, human embryo research including work to derive human embryonic stem cells would be prohibited. Those who oppose killing blastocysts for embryonic stem cell research have invoked Kant's imperative to argue that no embryos, at any stage of development, maybe killed to achieve the potential benefits of such research. Kant proscribes treating persons solely as a means to an end no matter what good can arise from doing so. According to these philosophers, by killing embryos for stem cell research, we are violating their dignity qua human beings, and thus violating Kant's imperative.

Due to the above argument, the essence of this paper is to explore Human Embryonic Stem Cell Research and Kantian Categorical Imperative. This work attempt to investigate critically to ascertain if human blastocysts can be covered under Kantian Categorical Imperative. This work calls into questions following the definition of 'person' as been 'rational', if human blastocysts can be said to hold what most ethicists call "rights of personhood"? Put simply, can Embryo be referred to as "persons"'? This work argues that if Kantians hold that respect for persons is only possible where persons possess capacities such as rational will and self-determination, they will hold that the human embryo is not a person and can, therefore, be researched upon and used to derive human embryonic stem cells.

\title{
KANT CATEGORICAL IMPERATIVE
}

Kant formulated his Categorical Imperative in several ways but the most relevant one tells us to Act in such a way that you always treat humanity, whether in your person or the person of any other, never simply as a means, but always at the same time as an end (Scarre 1998). This leads to the belief that individuals have certain inalienable rights, as embodied in the famous statement in the Declaration of Independence that all people are "endowed by their Creator with certain unalienable [sic] rights, that among these are life, liberty and the pursuit of happiness" (McCarty 2015). In practice, this means that a person's life cannot be sacrificed to achieve some greater good. Kant devised the Categorical Imperative the implicit moral command to which the voice of conscience, in his view, testifies, was designed to form the basis of all moral obligations. The categorical imperative is more open because the idea is more open, and the idea of an autonomous person as an 'end in itself' is a principle not only for some contexts of actions but for all kinds of human action. For Kant autonomy is the basis of the moral law and is therefore a notion that is important for all moral considerations. At the same time, the content of his principle is more determined, because it has to be seen in the context of his justification. With the foundation of his principle, Kant demonstrates the philosophical horizon that determines how the autonomous being is an end in itself. His principle and the notion of autonomy are therefore not empty labels open for any kind of content, but there is a theoretical framework as a reference 
point for discussion of a possible content of moral duties. Since the autonomous person is the basis of all our moral obligations (the lawmaker), this person is the non-arbitrary starting point of moral considerations. At the same time, Kant refers not only to the factual consensus concerning the moral validity of his principle, even though he thinks that our moral consciousness in everyday life comes to no different conclusions than the philosopher does.

Instead of referring to factual consensus, he shows why and in which respect his principle is morally valid, taking seriously the idea that with a moral obligation a claim is made that cannot be taken for granted. One remark has to be made concerning a criticism that is often made in bioethics against such an approach. It is criticized for being a top-down approach that deduces moral judgments from a single highest principle. That is a clear misunderstanding. Kant never defended the idea of a 'deduction' from the categorical imperative to a concrete moral judgment. The categorical imperative is a principle that we have to use for the examination of our maxims. But the maxims themselves are not deduced from the categorical imperative. There must be some maxims that can be examined in order to come to a concrete moral judgment. Since these maxims are not in a deductive or inductive relation to the moral principle, there is no deductive relation between the categorical imperative and the moral judgment.

Kant's moral philosophy is characterized by the principle that rational nature in the person of every human being is an end in itself, something that has an objective value that makes claims on us, and grounds rights, including the right not to be killed. According to Kant, persons, given their inherent value, ought never to be treated solely as a means to an end and hence must always be treated as ends in themselves. As Mappes and DeGrazia note, "In Kant's view, every person, by virtue of his or her humanity (i.e. rational nature) has inherent dignity. All persons, as rational creatures, are entitled to respect, not only from others but from themselves as well" (Masters 2012, p. 65). This means that every person must be treated with respect and that his or her dignity ought never to be violated; persons ought never to be treated as mere tools or instruments to achieve some end, no matter how grand those consequences may be. It is this idea of respect for persons that are applied to the human embryo and which causes huge amounts of debate and division amongst commentators.

If zygotes fall under the scope of Kant's formula of humanity version of the categorical imperative, then, for those who accept Kantian morality, it is hard to endorse the use of zygotes for stem cell research, even if they are slated for destruction. The common response to arguments of this type, using Kant's imperative, is put forth by Robert P. George as follows: "Never permit or fund the harvesting of organs from retarded human infants, demented, or terminally ill patients, or even death row prisoners. We wouldn't tolerate killing for purposes of harvesting body parts because it is inconsistent with the inherent dignity of all human beings" (Scoccia 1995, p. 54). Catholic theologian Richard Doerflinger writes along the same vein:

It is also argued that destructive harvesting of cells has a different moral character if it is only performed on "spare" embryos no longer needed by fertility clinics for reproductive purposes... but destroying individuals for body parts because he or she will "die soon anyway" is very different from harvesting tissues when that individual is already dead. If it is not, there is no moral difference between a modern transplant surgeon and Jack Kevorkian, who has proposed killing condemned prisoners (or terminal patients who want euthanasia) by removing their vital organs while they are still alive. Longstanding legal and moral traditions against active euthanasia reflect the principle that killing does not lose its moral significance simply because the victim "will soon anyway" (Doerflinger 2004, p. 72). 


\author{
$82 \mid$ Predestinasi \\ Volume 13, No. 2, Desember 2020 Hal. 79-92
}

Doerflinger and others who oppose stem cell research feel strongly that "the human individual is called into existence by God and must always be treated as an end in himself or herself" $(2004$, p. 76). This view is consonant with Kant's postulate that human beings are ends in themselves and not means to some other goal (Doerflinger 2004). Linking this belief to the position that human life begins at fertilization leads these thinkers to the conclusion that human life must be protected absolutely, especially at this vulnerable stage. Indeed, as argued by Gilbert Meilaender, the fact that great social good can come from research on human embryonic stem cells does not justify the destruction of human embryos (Rose 2017).

Embryo research "directly promotes the destruction of embryonic human life" and destruction of embryos represents "wrongful killing" (Doerflinger 2004). Regarding the acquisition of stem cells for research, Doerflinger (2004, pp. 65) states that these materials are "lethally harvested from embryos". The Catholic Church, as a monolithic entity, is opposed to all extracorporeal activities involving embryos. The Vatican's Instruction Dignitas Personae (2008) advises the faithful-"The fruit of human generation, from the first moment of its existence, that is to say, from the moment the zygote has formed, demands the unconditional respect that is morally due to the human being in his bodily and spiritual totality"-Embryos are "the subjects of essential rights and should, therefore, be protected by law as human persons". Experimentation on human embryos "constitutes a crime against their dignity as human beings, (and) always constitutes a grave moral disorder". "The use of embryonic stem cells even when these are provided by other researchers through the destruction of embryos presents serious problems from the standpoint of cooperation in evil and scandal". "The obtaining of stem cells from a living human embryo is consequently gravely illicit"“. (Rose 2017, p. 534).

Michael Novak is a distinguished American philosopher and one of the most articulate opponents of ESCR. His opposition, he declares in a recent article, is "principled," that is, philosophical. The "ground" of his opposition is, he says, "a philosophical one, not a theological one, a ground born of reason rather than of faith", (van Wyk 1974).

Michael Novak, in his article 'The Stem Cell Slide: Be Alert to the Beginnings of Evi', writes,

"You must never use a human being as means for even the noblest ends. To use stem cells obtained by killing living human beings in their embryonic stage is still using them as a means. It is not enough to say that the wicked deed has already been done the embryos have already been killed. The purpose of that killing was to obtain the stem cells. One ought not to implicate oneself in that process, not even for the noblest and most beautiful ends" (p. 102).

We find a similarity in killing persons who will die in a short period and killing doomed embryos by extracting their stem cells. In both cases, killing is done to facilitate stem cell research. Kant's imperative would seem to proscribe the premature killing of persons since persons do not lose their inherent dignity merely because their death is imminent. Killing someone does not become morally acceptable just because an individual will face death soon or because their death would contribute to overall utility. Similarly, the argument goes, it ought not to matter that leftover IVF embryos are inevitably slated to die after a period of being cryogenically frozen. Their impending"death does not render killing them morally permissible, not even to achieve the noble ends of attaining stem cells for potentially life-saving research.

Given that these embryos are going to be disposed of and thus have no chance of being implanted in a womb, the argument goes, shouldn't they be put to good use, not wasted, in research that may save the lives of many by allowing the stem cells to be extracted. Killing people who are already slated for death in order to save others would seem to be an unmitigated 
improvement to the world. From a consequentialist perspective, such killing seems obviously unproblematic. While some people embrace this view, others recoil from it in horror. Taking what they consider to be a deontological position, they deny the relevance of consequences. They believe that certain acts are always wrong. Killing, enslaving, torturing, stealing, lying, and so on are never justified by actual or intended consequences. No end justifies these means. Sometimes this view is phrased as the general principle that "evil shall not be done in order that good may come of it."

The question is, are human blastocysts covered by the Categorical Imperative? Do they have what ethicists call "rights of personhood"? Put simply, are they "persons"? Kant did not consider children to be persons in the fullest sense, as they do not yet have a developed ability to reason, but he still said they need to be protected as potential persons. Kant's first statement of the categorical imperative said that you should act according to maxims that you could to become universal laws. If you universalise experimenting on embryos, you hit a self-contradiction. If all embryos were experimented on, none would grow into humans, so such a law is not logically possible.

Oduncu (2003) argues that it is at conception when the sperm fertilizes the ovum, that the human person comes into existence: "The human embryo is looked upon as a human being from the moment of its conception and thus attributed the fundamental principle of human dignity that guarantees the right to life of the embryo" (Oduncu 2003, p. 896). It might be wondered what Kant himself thinks about the personhood of fetuses or embryos. The fact is that he never addresses such issues directly. Kant never commented directly on the moral status of the fetus or unborn child, though some of his remarks suggest that even newborns in his view may have lacked full moral standing $(1791,336)$. Kant does not specify exactly what a person is (nor does he defend his assertion that non-human animals are not persons), though clearly, a person must be a being with a will that can impose an obligation. In the introduction to the Metaphysics of Morals, Kant offers a "preliminary" exposition of the concept of moral personality:

A person is a subject whose actions can be imputed to him. Moral personality is therefore nothing other than the freedom of a rational being under moral laws (whereas psychological personality is merely the ability to be conscious of one's identity in different conditions of one's existence). From this, it follows that a person is subject to no other laws than those he gives to himself (either alone or at least along with others.) A thing is not capable of having anything imputed to it. Any object of free choice which itself lacks freedom is therefore called a thing (res corporalis) (Kant 1981, p. 336).

This passage begins like a mirror-image. It first characterizes personhood in terms of the capacities for responsibility and the freedom to stand under moral laws, which are found first and foremost in the obligated, rather than the obligator. Taken together, these suggest that while Kant distinguishes between active and passive obligation, he considers the relevant capacities to be connected. Persons are beings with free wills, standing under the moral law, whose wills can reciprocally obligate and be obligated by one other. Moral obligation is a relation between (perceptible) persons, between two distinct persons or of one person to him or herself. This conception of obligation and the basis of moral status fits well with each of Kant's familiar formulations of the supreme principle of morality in the Groundwork. The Formula of Universal Law commands each of us to act only on maxims that we can simultaneously will to be universal laws of volition. Each will is constrained by the idea of what can be a law for all wills. The Formula of Humanity requires each of us to treat each person as an end-in-itself. The Formula of Autonomy and The Formula of the Kingdom of Ends have us conceive of the moral law to which 


\author{
84| Predestinasi \\ Volume 13, No. 2, Desember 2020 Hal. 79-92
}

we are subject as a law that we legislate as and for members of a kingdom of ends. A union of rational beings is made possible by that law.

Grave problems are equating the Kantian concept of a person with a biological (species dependent) category. In the Metaphysics of Morals, Kant clearly defines "person" as a moral agent; as a being with certain cognitive capacities, "a subject whose actions can be imputed to him. Moral personality is therefore nothing other than the freedom of a rational being under moral laws"'(Kant 1791, p. 16). In his Religion within the Bounds of Mere Reason, Kant argues that the human capacity of "personality" is the source of our dignity as rational creatures, and he defines it as "the susceptibility to respect for the moral law as of itself a sufficient incentive of the power of choice." (Kant 1793, p. 27). And, once again in the Metaphysics of Morals, Kant specifically defines the term "humanity" as "the capacity to set oneself an end-any end whatsoever" (Kant 2019 , p. 142). It is clear from these passages that Kant correlated the capacity for free choice and moral agency with humanity and personhood. The problem for Kantian pro-life philosophers who argue that conception is the moment when a new human person first comes into existence is not just that embryos and fetuses lack moral agency and free will, but that Kant was clear that it was impossible to correlate the acquisition of freedom, and therefore humanity, to a physical or biological event.

According to Kant, human agency and free will cannot be connected in any way with any physical or empirical event, for all events of such sort unavoidably follow a necessary causal chain, whereas free will, by its very essence, cannot be subject to any such causation. Because of its liberation from any physical phenomena, Kant refers to human agency and free will as "transcendental freedom." According to Kant, free will and the moral agency must exist, for if not persons would lose the fundamental basis of their dignity. Moreover, the fact that persons recognize the value and the authority of the moral law serves as further evidence that the freedom to follow such laws must exist. Kant, therefore, distinguishes the phenomenal self (the component of human nature that is subject to physical causal laws) and the noumenal self (the component of human nature that exists independently of causal laws-the the purely intelligible self). Our noumenal selves, by definition, cannot be subject to any empirical or causal phenomenon, and it is this part of ourselves that accounts for our free will and agency. Since the source of our personhood/humanity, and therefore our dignity, is our free agency, and because that agency is transcendental, this means that we cannot render our personhood dependent on any biological or empirical phenomena. In other words, any attempt to tie the genesis of a Kantian person to a biological event (such as conception) would run counter to Kant's claim that personhood is purely noumenal or transcendental. Personhood, then, would be an empirical occurrence, subject to the causal laws of nature, and therefore there would be no genuine free moral agency. Indeed, Kant himself is very explicit about this in his Metaphysics of Morals: "it is impossible to form a concept of the production of a being endowed with freedom through a physical operation" (Kant 2019, p. 137).

This presents a formidable challenge to Kantian pro-life arguments that rely on the embryo or fetus's species membership as grounds for the attribution of personhood, and that traces the beginning of a person to a biological event (conception). Unless these philosophers can show that embryos or fetuses possess a transcendental self (which will be difficult to do given that Kant clearly correlates the possession of such self to certain cognitive capacities), or that it is at conception where the transcendental self somehow merges with the empirical self (a kind of Kantian immediate animation), they cannot maintain that embryos and fetuses are persons in the same way you and I are persons. Consequently, they have not provided an argument concerning 
why the formula of humanity applies to embryos and fetuses, and so they lose this theoretical ground against abortion or embryo experimentation.

\section{KANTIAN ETHICS AND RESPECT}

The notion of person is explicitly used by Kant in the second formulation of the imperative, which runs as follows: "Act so that you treat humanity, whether in your own person or in that of another, always as an end and never as a means only" (Kant 2019, p. 156). Let me, first of all, restate the Kantian imperative as follows: always treat every person as an end in him or herself and never as a means only. This version bypasses the reference to humanity since Kant seems to imply that humanity is to be treated as an end in every real person. The reference to humanity as a general concept gives the impression that it is an abstract, impersonal value. But if humanity is really given in persons only, then the imperative commands us to treat persons as ends, as real instances of living individuals of a rational nature (where rational nature is the same as humanity). We can now introduce a second modification. Assuming that to treat a person as an end and not as a means only is, in a strong and deep sense, to respect him or her. We might reformulate the imperative as follows: always act so that you respect every person, yourself or any other (or in short: respect every person, yourself or any other). Kant does not use the verb "to respect" (achten) in this sense, because he thinks that respect (Achtung) is a feeling (Gefühl) and therefore a merely passive affection, albeit one with an intellectual basis (Kant 2019)

But what are the features of persons that make this respect possible? Why do we treat persons as an end and never simply as a means? I feel it necessary to discuss, following Kant, whether embryos are people to whom we need to show respect? Downie and Telfer expand upon the idea of respect for persons when they state that: "...the meaning of the injunction to treat and regard people not merely as a means but also as ends is that we ought to treat them as valuable in themselves and not only as useful instruments...to respect a person as an end is to respect him for those features which make him what he is as a person and which, when developed, constitute his flourishing" (Downie \& Telfer 1969).

We may call this the principle of respect for persons, and consider it as the Fundamental principle of morality. In a Kantian framework, such a principle is underived and so does not need a deductive justification, but it can be shown reflectively that all the works of reason in guiding action (i.e. practical reason) spring from it. Kant suggested that any rational choice implies conformity to certain necessary requirements that can be expressed only by the idea of a Categorical Imperative. These are, p. firstly conformity to the formal requirement of universality; secondly, the material requirement of a necessary end, which for morality must be an end in itself, and only rational natures are ends in themselves since only they can act for freely chosen purposes; and thirdly the requirement of a complete determination of the will in the light of mutual accordance between rational beings as ends in themselves (the "kingdom of ends").

There are two major differences between our principle of "respect for persons" and the Kantian wording of the Categorical Imperative (in its second formulation): the use of the verb "to respect", and the central, rather than incidental, position occupied by the noun "person". I think that these changes can be justified in a perspective that is still typically Kantian, although they introduce views that Kant did not explicitly hold. Let us start with "respect". Kant's notion of respect refers to the feeling aroused by the awareness of the moral law in rational creatures: it is a special kind of feeling, caused not by sensibility but by practical reason alone. Respect is the 


\author{
86 Predestinasi \\ Volume 13, No. 2, Desember 2020 Hal. 79-92
}

emotional response to the awareness of the moral law within ourselves, and it becomes the motive of practical reason, generated by that.

Yet there is no reason to confine ourselves to this rather reductive understanding of respect. We may also consider respect as a practical disposition, not simply a feeling but an attitude of the will that consists in considering every person as an end in him or herself. In fact, we may transform our emotional response into an attitude of the will, precisely through reflection. As Christine Korsgaard suggests (McDonald 2010), it is by way of a "reflective endorsement" that we adopt the maxims that guide our actions. In this case, we reflectively adopt the maxim to treat every person as an end is to respect them. Here, respect is not just a feeling; it is also an attitude belonging to the rational dimension of the person, a deliberate direction of the will towards treating the person as an end. To respect persons is not to use them simply as means, and it results from a deliberation about how to act rationally, from an interpretation of what is entailed in the first principle of morality. This might not be a dramatic shift in meaning, but it is important since it makes clear that "respect", in this sense, is not merely a passive attitude but rather an active power that is translated on a practical level to the recognition of the other person as an end in him or herself.

But there is more than this: respect implies that the agent recognizes the object of his action as a kind of reality deserving that disposition. I must realize that I am a person and that the other is a person, in order to respect myself or any other. But here we have another step in the direction of intersubjectivity: recognition in this sense implies a dialectic, which Hegel developed in the Phänomenologie des Geistes (Hegel 1977), and which has been further explored by phenomenological and existentialist thought. The need for recognition is the source of any intra - and interpersonal relationship, and its core is the permanent polarity of self and other, of identity and difference, inscribed in each person (myself as another), and in any form of communication (the other as a self). The dynamics of recognition also recall the issue of personal identity. The recognition of my nature as a person and of my personal identity as "myself" (as distinct from any other) both depend on the encounter with other persons (or selves), and on the interplay between my choices, actions and feelings and those of others. At the same time, without the recognition of myself for who I am, I cannot truly be respected by others. To be treated impersonally appears to us as a form of disrespect to which we react in ways not so different from those we adopt to protect our physical integrity. The dialectic of recognition, implied in the notion and practice of respect, opens a relational, dialogical dimension within the apparently strictly mono logical Kantian principle. If this holds, we might even restate the first formula of the Categorical Imperative, and say that the test for my maxim is: "Could this maxim be willed by any other person as an instance of respect for every person?"'

Thus, respect implies recognition, and recognition requires reciprocity. I cannot respect any other if I do not recognize the other as a self (a person), nor can I respect myself if I consider myself a mere thing. In this sense, recognition of the other as a person is a necessary step once the principle of respect is brought to consciousness through reflection. Furthermore, I cannot pretend to consider myself a person, and therefore the object of respect, if I am not willing to respect other persons as well. Reciprocity in this sense seems to be implied in my claim for respect. In the words of Thomas Nagel, considering oneself "as a person among other persons" appears to be a prerequisite of morality (Nagel 1970). If, as I contend, treating humanity as an end in itself means respecting every person, then the explicit mention of the idea of respect seems to clarify the Categorical Imperative in a way that emphasises intersubjectivity and relationality. 
We might now reformulate the fundamental principle (in a way which moves slightly away from Kant) as follows: respect yourself as another, and any other as yourself.

\section{KANTIAN ETHICS, RATIONALITY AND HUMAN DIGNITY}

Usually, Kant applies the word "person" to rational beings considered as "Ends" in reason itself. Kant does not seem to think that respect could be more than themselves. "Personality" is the quality that makes individuals of a rational nature worthy of respect: it is the mark of their "dignity". Kant simply states that this dignity is the fact that "the rational nature is an end in itself", while no other reality in the world is. This is why we call every rational nature a person and not a thing. It seems then that "person" indicates the idea of a rational nature specifically seen from a moral point of view, as "that reality which is intrinsically worthy of respect". The concept of person is primarily a moral one, and it seems that Kant would admit something like intuition or an intuitive knowledge or recognition of persons, at least in the sense that in the presence of fully developed persons we immediately recognize their value as ends in themselves, even though we may not yet be able to apply the notion of person in marginal cases.

Kant uses the notion of person to indicate every individual instance of rational nature in its dignity of an end in itself. Thus it seems wrong to argue that Kant's notion of person is simply that of a "mere logical subject of acts of reason" as Max Scheler contended in chapter VI of Der Formalismus in der Ethik und die materiale Wertethik (Czerniak 2018). Individuality is indeed excluded from humanity as a general concept, but not from persons as such, whom Kant always considered as individual instances whose common nature implies both universal and individual traits.

In the second formulation of the Categorical Imperative, the word "person" does not indicate the rational nature in an abstract sense, but every single concrete individual in which we find humanity. Humanity must be considered as an end in itself, in every person, yourself or any other. The incidental phrase pointing to persons makes it clear that Kant says "the matter" of our actions are not abstract notions as humanity or rational nature, but real individuals. Yet, Kant's concept of person is unquestionably rather abstract, meaning in a strict sense: "any occurrence of rational nature as an end in itself". Although this notion is very rich and echoes the classical definition of the person given by Boethius (rational is naturae individua substantia), it does not make clear the role assigned to individual identity in the moral norms based on the fundamental principle. The classical definition explicitly mentions individuality (individua substantia) as a principle of distinction identifying the single instances of the idea of a rational nature. Kant's moral philosophy is characterized by the principle that rational nature in the person of every human being is an end in itself, something that has an objective value that makes claims on us, and grounds rights, including the right not to be killed. Rational nature for Kant is also the capacity for autonomy, or rational self-government, which in Kant's view has dignity or an absolute worth that cannot be justifiably traded off against the worth of anything else. Kant has the reputation (partly deserved, but partly based on misunderstandings) of having been extremely inflexible on certain moral issues, and infamously unwilling to admit exceptions to some moral rules. However, I do not think that a general spirit of inflexibility in applying moral rules would be part of, or even minimally consistent with, the basic principles of the Kantian theory. Whatever Kant's own views on particular issues may have been, a Kantian should go with the basic principle and be prepared to jettison Kant's particular moral opinions, which often reflect the prejudices of his time or his own idiosyncrasies and are not required by his principles. 


\author{
88 Predestinasi \\ Volume 13, No. 2, Desember 2020 Hal. 79-92
}

Why did Kant think that rational nature in persons is an end in itself? As I interpret him, Kant thinks that we cannot employ reason in making decisions without according a special and primary value to rational nature in ourselves, and therefore, if we are consistent, equally in others also. It is the possession of the capacity to act rationally, especially the capacity to act autonomously, which fundamentally makes a being a person. The fundamental claim made on us by the value of rational nature is the claim that we express respect for rational nature in the way we act, especially in the way we act toward persons. The Kantian view is therefore a version of the view to which David Oderberg (1997) applies (with corresponding disapproval) the ugly neologism "personism." That is, Kant's fundamental moral principle does not entail that all living beings of the human species are persons; it grounds personhood in the possession of capacities that not all humans, in fact, have, and that might also in principle be possessed by nonhumans.

For Kant, a person is a being capable of making rational decisions, and being held responsible (morally as well as legally) for its actions (Kant 1791, p. 223). In this sense, and within our experience, all and only normal adult human beings are persons. Thus our starting point for deciding who should possess the rights of persons, such as the right not to be killed, must be with normal human adults. I will call these beings " persons in the strict sense." But the more basic principle that should determine to what entities the rights of persons pertains is that we should so act as to respect the value of the humanity or rational nature that makes any being a person in this sense. This might easily lead us to expand the class of beings we regard as persons to ascribe some rights to them, such as the right not to be killed. Let us call these other beings "persons in the extended sense. For instance, children who cannot yet exercise rational agency, or who have it only to a certain degree, and also adults who have temporarily lost their rational capacity, should be treated for many purposes just as persons should be treated.

The Kantian line of thinking that leads to this conclusion, I submit, is this: we would not show proper respect for the rational nature of persons in general if we did not treat temporarily incapacitated or immature rational agents as persons, thinking about them in certain respects just as we think about persons in the strict sense, and according to them certain rights, including the right not to be killed, just as we do persons in the strict sense. Persons in the extended sense may not possess all the same rights as persons in the strict sense. Because children cannot direct their own lives without the guidance of others, they cannot have the same right to direct their lives that adults do. But for just the same reason, society owes greater care for their interests than it does for the interests of those who can look after their interests themselves. But persons in the extended sense have the same right not to be killed, for instance, as persons in the strict sense. The rights of personhood in the extended sense might vary depending on why it is that the human being is not a person in the strict sense; hence personhood in the extended sense may be in some ways be a different status from personhood in the strict sense, but it is not a lesser status.

The obvious question, given our present concerns, now is: How widely should we apply the notion of personhood in the extended sense? Does it apply to all phases of the existence of beings who are (or may at some time, under any conceivable circumstances, come to be) persons in the strict sense? Does it extend even to fetuses? Even to embryos? Even to embryos located outside a uterus that can become persons only if extraordinary measures are taken to implant them in a uterus? The crucial question, as I see it, at least from a Kantian standpoint, is: What actions, affecting such beings, are required by a proper expression of respect for rational nature? To answer this question we must consider more than merely what our actions express toward those potential persons. For if preventing a fetus from being killed also involves infringement of the 
freedom of a person in the strict sense to control the life processes going on in her own body, then the preservation of the life of that fetus or embryo by forcibly violating that freedom expresses extreme disrespect for the humanity of a person. If preserving the life of an embryo would require extraordinary measures, and also stand in the way of scientific research that promises to extend the lives and protect the rational capacities of many persons in the strict sense, then preserving the life of that embryo expresses, on the whole, gross disrespect for rational nature.

From a Kantian standpoint, therefore, social policies that would compel a woman to bear a child, and that would block vital medical research, are not at all moral requirements. In fact, I think that they are mindless moral obscenities, unthinking remnants of traditional morality that has refused to face the choices with which we are faced in light of modern medical technologies and a modern scientific understanding of human life. A fetus or embryo, which is definitely not a person in the strict sense, is also not to be considered a person in the extended sense. Because it is a potential person, there is surely some value in its life, which needs to be weighed in making decisions about when and how to preserve or destroy that life. But such merely potential persons should not share in the rights of persons in the strict sense, such as the right not to be killed. Broadly speaking, birth is the most natural dividing line between persons in the extended sense and beings whose existence may have value. For preserving life before birth by enforceable right requires encroachment on the rights of a person in the strict sense, whereas after birth there is at least the possibility in principle of protecting the being's life without doing this. This consideration is not, and is not intended to be, as absolute, as those usually advanced by the proponents of the view that fetuses and embryos have a right to life. But it might be all the more sound for that difference.

Advocates of a more restrictive interpretation contend that on Kant's personhood criterion many human beings, including normal human infants and seriously (even if only temporarily) cognitively disabled human adults, must lack moral status. Construed most narrowly, Kant's cited claim (Kant 1791 , p. 223) about imputability or responsibility may suggest the following criteria for moral status: an individual is a person and has moral status if and only if it is reasonable to hold her morally responsible for some action. Since there is nothing for which we would hold human infants or severely cognitively disabled adults morally responsible, it is argued, such humans must lack Kantian moral status. However, some Kantians believe that the embryo is not yet a potential person. Bertha Manninen argues that becoming a Kantian person is not a physical change, as there is something transcendental about being a reasoning being: "The capacity for reason, according to Kant, is a supersensible capacity, given that the possession of transcendental freedom is a necessary precondition for possessing this capacity" (Manninen 2008, p. 53).

Human dignity stands for a certain self-understanding of humans living together and organizing society and, although it has to be ascribed, there has to be a convincing way of doing so which then needs to be protected against incremental erosion (Hauskeller, 2004). Habermas claims Human dignity, its ascription and protection is the concept in which we frame this fundamental presupposition of a shared value that is independent of any particular characteristics of individuals). The Kantian idea that we have to respect human dignity in ourselves and others may lead us towards a reconsideration of biomedical research in a way other than the one mainly pursued in contemporary bioethical reasoning when the dignity of the other who might be an embryo is considered. It could be asked whether some of the practices intrinsic to the research deaden the ethical receptivity of those who get used to them. To respect the vulnerability of the human self and the human body it might be more appropriate to study the effects of the practices employed in present biomedical research and practice and how they are thought of and exercised. 
90 Predestinasi

Volume 13, No. 2, Desember 2020 Hal. 79-92

The extraction of stem cells from aborted fetuses and frozen embryos might then be revealed not to be more harmful to those who do it than the extraction of organs from dead bodies is to other practitioners of biomedicine. How we practice medicine and perform research might be of the same importance for the everyday valuation and protection of human dignity as the regulatory protection of certain valuable others.

Kant believed in God but didn't believe that morality should be simply a matter of obeying commands from God (Edet 2015; Edet 2019). Rather, he thought that morality should be about discovering what was acceptable to everyone who was able to think rationally about being moral. This approach, he believed, should lead humans to establish universal moral principles that could be embraced by everyone. If the fetus is, strictly speaking, a member of the animal kingdom, then human beings have no duties towards them and hence can treat the fetus as a means to an end. This means that a mother's right to ownership and control over her own body can override the right of the fetus to life. So a fetus can be aborted quite legitimately so long as the fetus is deemed a non-rational being. All of the above holds for the embryo as well. Potential rational life is NOT actual rational life and so a Kantian would have no problem concerning embryo research. Persons who care passionately about the sanctity of life are important participants in the moral dialogue concerning how to conduct our medical practices. Such voices are a reminder to us that we cannot sacrifice the rights of the individual for the good of the many. I have attempted to establish that we are not sacrificing the embryonic persons' right not to be harmed or treated in such a manner to which a reasonable person (such as oneself) would object. As science advances, there might come a day when there is no longer any need to use embryonic stem cells. Even if this occurs, it will still be worthwhile to know whether ESCR is one of several morally viable alternatives for obtaining stem cells.

\section{CONCLUSION}

I have shown that, for Kant, to be a person one must be rational, free and subject to the moral law. I can be constrained by others to perform actions that are directed as means to an end, but I can never be constrained by others to have an end', only I myself can make something my end. Kant goes further to say that if another person compels me to have an end it is a selfcontradiction, it is "an act of freedom which is at the same time not free." Therefore, an end is a person's own end only if it is chosen through free will. It can be inferred from the above arguments that in the absence of all of these capacities a being cannot be recognised as human and as such makes respect for persons impossible and would equally allow the use of that being as merely a means to an end. It is the recognition of the essential capacities which make respect possible and helps us to follow the Kantian maxim to never treat persons merely as a means but always as an end in themselves. If followers of Kant's Categorical Imperative hold that respect for persons is only possible where persons possess capacities such as rational will and self-determination, they will hold that the human embryo is not a person and can, therefore, be researched upon and used to derive human embryonic stem cells.

\section{REFERENCES}

Czerniak, S. (2018). Max Scheler-Bernhard Waldenfels. Dialogue and Universalism, 28(4), 5373. https:doi.org/10.5840/du201828454 
Doerflinger R. M. (1999). Destructive stem-cell research on human embryos". Origins, 28(45),771-3.

Doerflinger, R. (2004). Testimony on embryonic stem cell research. Origins, 34(23), 367-373.

Downie, R. S. \& Telfer, E. I. (1969). Respect for Persons. George Allen and Unwin Ltd.

EDET, F. F. (2015). BOKO HARAM: A LEGAL AND BIBLICAL PERSPECTIVE. JOURNAL OF INTEGRATIVE HUMANISM GHANA, 94.

Edet, F. F. (2019). Dress code for women in Islam: a sociological investigation. Lwati: A Journal of Contemporary Research, 16(3), 182-188.

Edet, F. F. (2019). The concept of worship in Islam. Lwati: A Journal of Contemporary Research, 16(4), 125-130.

Hauskeller, C. (2004). How traditions of ethical reasoning and institutional processes shape stem cell research in the UK. Journal of Medicine and Philosophy, 29(5), pp. 509-532.

Hegel, G. W. F. (1977). La phénoménologie de l'esprit. Tome I. In Philosophie de l'esprit, Vol. Aubier (p. 358).

Kant, I. (1791). Critique of Pure Reason. Translated by Norman Kemp.

Kant, I. (1950). The Moral Law. Translated by H J. Paton. New York: Bames and Noble, Inc.

Kant, I. (1981). Grounding for the Metaphysics of Morals. Translated by James W. Ellington. Cambridge: Hackett Publishing Co., 1981

Kant, I. (2019). The Metaphysics of Morals. In Kant: Political Writings (pp. 131-175). https:.//doi.org/10.1017/cbo9780511809620.008

Kant, I. (1793). Religion within the Limits of Reason Alone. Harper Torchbooks; Later prt.

Kitcher, P. (2004). Kant's argument for the categorical imperative. Nous, 38(4), 555-584.

Manninen B. A. (2008). Are human embryos Kantian persons?: Kantian considerations in favor of embryonic stem cell research. Philosophy, Ethics, and Humanities in Medicine 2(8).

Master, Z. (2018). Ethics of issues and stem cell research, p. The unresolved issues. In Encyclopedia of Biomedical Engineering (Vols. 1-3, pp. 584-597). https://doi.org/10.1016/B978-0-12-801238-3.00021-0

Masters, B. R. (2012). Biomedical ethics, 7th edition David DeGrazia, Thomas A. Mappes, Jeffrey Brand-Ballard. Graefe's Archive for Clinical and Experimental Ophthalmology, 250(1), 159-160. https:doi.org/10.1007/s00417-011-1640-x

McCarty, R. (2015). False negatives of the categorical imperative. Mind, 124(493), 177-200. https://doi.org/10.1093/mind/fzu151

McDonald, F. J. (2010). Christine M. Korsgaard, The Constitution of Agency. Ethical Theory and Moral Practice, 13(2), 235-236. https://doi.org/10.1007/s10677-009-9195-1

Myskja, B. K. (2008). The categorical imperative and the ethics of trust. Ethics and Information Technology, 10(4), 213-220. https://doi.org/10.1007/s10676-008-9173-7

Nagel, T. (1970). The Possibility of Altruism. Clarendon Press, Oxford.

Novak, M. (2003). The Stem Cell Slide, p. Be Alert to the Beginnings of Evil',. The Stem Cell Controversy, p. Debating the Issues. Eds Michael Ruse and Christopher Pynes. Amherst NY: Promethus Books.

Oderberg, D. S. (1997). Modal Properties, Moral Status, and Identity. Philosophy and Public Affairs 26(3).

Oduncu, F. S. (2003). Stem Cell research in Germany, p. Ethics of Healing vs Human dignity Medicine. Health care and Philosophy 6(1).

Rose, M. (2017). Introduction to gilbert meilaender symposium. In Studies in Christian Ethics (Vol. 30, Issue 2, pp. 131-132). https:doi.org/10.1177/0953946816684074 


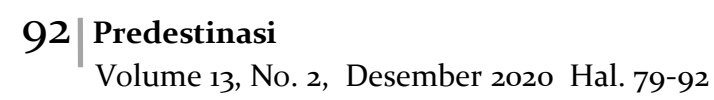

Sasa, M. S. (2019). An Appraisal of the Concept of Beauty in Immanuel Kant's Philosophy. GNOSI, p. An Interdisciplinary Journal of Human Theory and Praxis, 2(2), 87-97.

Scarre, G. (1998). Interpreting the categorical imperative. British Journal for the History of Philosophy, 6(2), 223-236. https://doi.org/10.1080/09608788808570992

Scoccia, D. (1995). Making Men Moral. Robert P. George. Ethics, 105(4), 943-945. https://doi.org/10.1086/293763

van Wyk, R. N. (1974). Michael Novak on the existence of God. International Journal for Philosophy of Religion, 5(1), 61-63. https://doi.org/10.1007/BF00143639 